\title{
Aflatoxins in Walnut (Juglans regiaL.), Pecan (Caryaillinoinensis (Wangenh.) K. Koch) and Cashew (Anacardium occidentale L.) Nuts of Mexico
}

\section{José Adaya-González ${ }^{1}$, Magda Carvajal-Moreno ${ }^{1 *}$, Francisco Rojo-Callejas ${ }^{2}$ and Silvia Ruiz-Velasco ${ }^{3}$}

${ }^{1}$ Laboratorio de Micotoxinas, Departamento de Botánica, Instituto de Biología, Universidad Nacional Autónoma de México (UNAM), Ciudad Universitaria, Coyoacán 04510, México

${ }^{2}$ Departamento de Química Analítica, Facultad de Química, UNAM, Ciudad Universitaria, Coyoacán 04510, México DF. Francisco Rojo is MSc in Analytical Chemistry, México

${ }^{3}$ Departamento de Probabilidad y Estadística, Instituto de Investigaciones en Matemáticas Aplicadas y en Sistemas, UNAM, Ciudad Universitaria, Coyoacán 04510, México

\begin{abstract}
Aflatoxins (AF) are toxic and carcinogenic secondary metabolites produced by Aspergillus molds, in oilseeds.

Objective: To identify and quantify $A F\left(A_{1} B_{1}, A F B_{2}, A F G_{1}\right.$ and $\left.A F G_{2}\right)$ in walnuts, pecans and cashews consumed in Mexico using a validated method.

Methods: The nut sampling was conducted in the three main markets of the 16 boroughs of Mexico City. The samples were homogenized, the extraction method was validated, and the concentrations of the 4 AF were determined by immunoaffinity columns. The identification and quantification of the AF was carried out by high performance liquid chromatography. A statistical analysis included the Wilcoxon/Kruskal-Wallis test to compare the variation of the origin of samples, types of AF and nut.

Results: The recovery percentages of the AF ranged from $75 \%$ to $95 \%$. The limits of detection (LOD) of the $\mathrm{AF}(\mathrm{ng} / \mathrm{g})$, based on the calibration curves, were: $0.1\left(\mathrm{AFB}_{1}\right), 0.01\left(\mathrm{AFB}_{2}\right), 0.01\left(\mathrm{AFG}_{1}\right)$ and $0.05\left(\mathrm{AFG}_{2}\right)$. Of the 50 samples analyzed, $22 \%$ were contaminated with $A F B_{1}$, and $100 \%$ were contaminated with $A F t$. The average concentrations of $A F$ in the walnut were $0.05 \mathrm{ng} / \mathrm{g}$ of $A F B_{1}$ and $2.10 \mathrm{ng} / \mathrm{g}$ of $A F t$. For the pecan, the concentrations were $0.09 \mathrm{ng} / \mathrm{g}$ of $\mathrm{AFB}_{1}$ and $0.44 \mathrm{ng} / \mathrm{g} \mathrm{AFt}$, and for the cashew, $0.02 \mathrm{ng} / \mathrm{g}$ of $\mathrm{AFB}$, and $1.36 \mathrm{ng} / \mathrm{g} \mathrm{AFt}$. The walnut was the most significantly $(p<0.05)$ contaminated by $A F B_{1}, A F B_{2}, A F G_{1}, A F G_{2}$ and $A F t$, and the most contaminated boroughs with $A F B_{1}$ were Tlalpan $(0.23 \mathrm{ng} / \mathrm{g})$ and Coyoacan $(0.26 \mathrm{ng} / \mathrm{g})$. For the pecan and cashew, no significant difference was found between the boroughs in $\mathrm{AFB}_{1}$ and AFt contamination.
\end{abstract}

Conclusion: Aflatoxins are potent mutagens and proven carcinogens, Type I for humans that should be prevented to warranty the quality of oilseeds, nuts are a source of carcinogen ingestion and their consumption can be a risk to human health.

Keywords: Aflatoxins; Nuts; Carcinogens; Mutagens; Food contamination; Mycotoxins.

\section{Introduction}

The world's production of unshelled nuts in 2010 was $2,545,388$ tons, and the main nut production countries were China $(1,060,600$ tons), the United States of America (458,000 tons), Iran (270,300 tons), Turkey (178,142 tons), Ukraine (87,400 tons) and Mexico (76,627 tons). The countries with the highest nut consumption by inhabitant during 2009 were Lebanon $(15.9 \mathrm{~kg})$, Maldives $(13.7 \mathrm{~kg})$, Greece $(11.1$ $\mathrm{kg})$, Iran (10.2 kg), Syria (10.1 kg), The Netherlands $(8.7 \mathrm{~kg})$, Spain $(8.6$ $\mathrm{kg})$, Switzerland $(8.4 \mathrm{~kg})$, Italy $(7.4 \mathrm{~kg})$ and Austria $(7 \mathrm{~kg})$. Mexico had a 1.8-kg consumption [1].

The estimated current population of Mexico was approximately $123,278,559$ in March of 2014 [2]. Mexico City includes the capital city called Federal District, which is home to 9 million inhabitants, while the entire metropolitan area had a population of 21.2 million people in 2013 [2]. This metropolitan area has 60 municipalities from the surrounding State of Mexico and one from the State of Hidalgo. Mexico City has $20 \%$ of Mexico's entire population, making it the most populous metropolitan area in the Western Hemisphere, four times the population of Norway or Denmark, and twice the population of Sweden. Mexico City is the third most densely populated city in the world after Tokyo and Delhi [3]. The Federal District is divided into 16 boroughs, which had the high populations in 2010 [4]. The Federal
District receives food from the entire country and is a reliable sampling place to gain an understanding of the nuts consumed in Mexico.

Aflatoxins (AF) are toxic secondary metabolites that correspond to bis-dihydrofurane coumarins [5-7] and are produced by the molds A. flavus, A. parasiticus, A. nomius, A. pseudotamarii [8] and A. bombycis [9] that can grow on the field, soil, debris, straw, or in storage warehouses [10] with low humidity and high osmotic pressure [11].

During 2011, Jalisco was the main production state for the walnut (Juglans regia $\mathrm{L}$.), and in total, Mexico sowed a total of 511.75 hectares (Ha) of walnuts, yielding 2.78 tons/Ha with a crop value of 2,044,840 USD. Chihuahua was the main production state for the pecan (Carya

*Corresponding author: Magda Carvajal-Moreno, Laboratorio de Micotoxinas C-119, Departamento de Botánica, Instituto de Biología, Universidad Naciona Autónoma de México (UNAM), Ciudad Universitaria, Coyoacán 04510, México Tel: +(5255) 5622 9138; Fax: +(5255) 5550 1760; E-mail: magdac@ib.unam.mx

Received December 05, 2014; Accepted February 02, 2015; Published February 06, 2015

Citation: Adaya-González, J, Carvajal-Moreno, M, Rojo-Callejas, F and Ruiz Velasco, S.(2015) Aflatoxins in Walnut (Juglans regia L.), Pecan (Carya illinoinensis (Wangenh.) K. Koch) and Cashew (Anacardium occidentale L.) Nuts of Mexico. Pharm Anal Acta 6: 338. doi:10.4172/2153-2435.1000338

Copyright: (C) 2015 Adaya-González J, et al. This is an open-access article distributed under the terms of the Creative Commons Attribution License, which permits unrestricted use, distribution, and reproduction in any medium, provided the original author and source are credited. 
Citation: Citation: Adaya-González, J, Carvajal-Moreno, M, Rojo-Callejas, F and Ruiz-Velasco, S.(2015) Aflatoxins in Walnut (Juglans regia L.), Pecan (Carya illinoinensis (Wangenh.) K. Koch) and Cashew (Anacardium occidentale L.) Nuts of Mexico. Pharm Anal Acta 6: 338. doi:10.4172/2153-2435.1000338

Page 2 of 10

illinoinensis (Wangenh.) K. Koch), and the country sowed 95,668 Ha, with a yield of 1.41 ton /Ha and a crop value of 457,977,252 USD. Finally, Chiapas was the main production State for the cashew (Anacardium occidentale L.), with the entire country sowing $1,232 \mathrm{Ha}$, and yielding 3.53 tons/Ha and a crop value of 1,311,031 USD, considering a money conversion of 13.10 Mexican pesos per USD on August 26, 2014 [12] (Figure 1). The nutrimental value of the three types of nuts has been reported [13].

Oilseeds, such as nuts $[8,14]$, cereals [15] and spices are susceptible crops to molds and their toxins, including AF [16]. Although $18 \mathrm{AF}$ have been identified, only four, Aflatoxin $B_{1}\left(A F B_{1}\right)$, Aflatoxin $B_{2}$ $\left(\mathrm{AFB}_{2}\right)$, Aflatoxin $\mathrm{G}_{1}\left(\mathrm{AFG}_{1}\right)$ and Aflatoxin $\mathrm{G}_{2}\left(\mathrm{AFG}_{2}\right)$, are common in oilseeds, many foods and feed [17] and are, thus, a risk for animal and human health due to their worldwide frequency [18]. Other AF ( $M_{1}$, $M_{2}, P_{1}, Q_{1}, G_{2 a}, B_{2 a}$, aflatoxicol, etc.) are products of microbial or animal metabolism [19].

$\mathrm{AFB}_{1}$ is the most potent carcinogen that affects the human liver [20] and has been classified as a Group 1 proven carcinogen for humans [21], based on epidemiological studies that associated it with liver cancer and acute hepatitis [22]. $\mathrm{AFB}_{1}$ is also teratogenic, abortive [23], mutagenic [24], and immunosuppressive [25]. It weakens veins and artery walls, breaks platelets and causes internal hemorrhages [26].

Acute intoxications or aflatoxicoses cause vomiting, abdominal pain, lung edema, fat infiltration with fat and necrotic liver $[27,28]$ and can even lead to fast death. The most important chronic AF diseases are hepatic diseases and cancers in humans [18,29,30], with 600,000 deaths per year [31,32] and survival of less than a year after diagnosis [33]. Mexico has the most liver diseases (e.g., cirrhosis, hepatitis and cancer) of all countries on the American continent [34], and Mexicans eat more maize and spices, such as chili, but the AF contamination of nuts have not been reported, and all the AF sources have to be described to prevent this problem. Although nuts are well known as susceptible to AF, there are no AF contamination in walnut, pecan or cashew reported for Mexico. Of the 64,000 cancer deaths in México, liver cancer accounts for $13.5 \%$ of the deaths [35]. AF are also related to the human papilloma virus in human cervical cancer [36], as well as colorectal, pancreas, and lung cancer [37]. Other chronic effects of AF are Reye syndrome [38], biliary duct proliferation [39], marasmus and kwashiorkor [40], which are associated with malnutrition, hepatitis, cirrhosis [41] and growth failure in children [42].

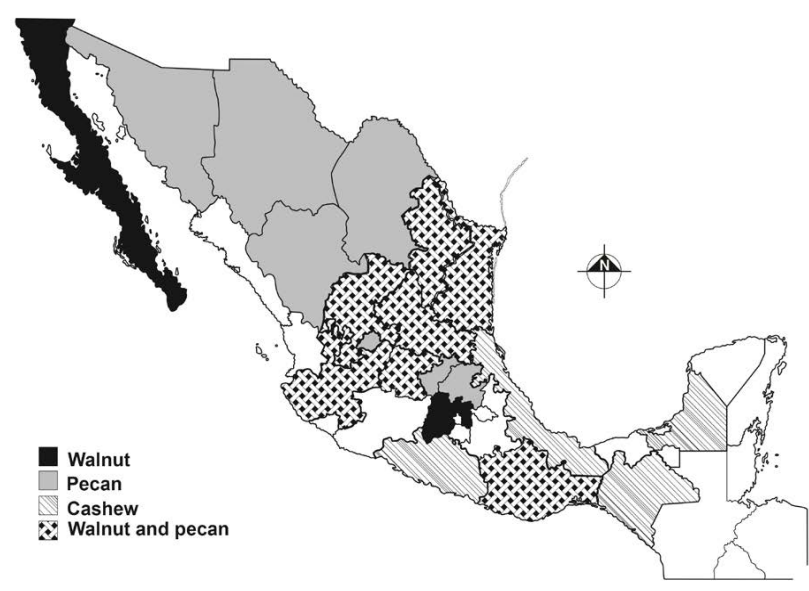

Figure 1: Mexican States that produce nuts.
In West India in 1970, several persons died from AF poisoning when they consumed AF-contaminated maize [41]. In 1995, the consumption of rice spaghetti contaminated with AF caused brain damage, encephalopathy, and acute damage in the livers of children from Malaysia [43]. Several human deaths were reported due to the consumption of AF-contaminated foods in Kenya in 1980 [44]. In rural Kenya in 2005, there were 317 aflatoxicosis cases that led to 125 deaths from eating AF-contaminated maize [30].

The production or inadequate storage conditions of food favors AF production in oilseeds, such as nuts [45]. AF have been detected in walnuts in Turkey [46], Morocco [47], and Pakistan [48] and in pecans that contain Aspergillus flavus and A. parasiticus, which are molds that produce $\mathrm{AFB}_{1}$ and $\mathrm{AFG}_{1}$ [49], cashews [50], almonds, pistachios, and hazelnuts when the nut is still in the tree with or without damage $[49,51,52]$.

AF levels do not diminish with domestic cooking in either a microwave [53] or gas oven [54]. High concentrations of $\mathrm{AFB}_{1}$ were detected under storage conditions of $97 \%$ relative humidity $(\mathrm{RH})$ and temperatures of 25 to $30^{\circ} \mathrm{C}$. Stored nuts were protected from AF for two months at a $\mathrm{RH}$ of 75 to $97 \%$ and a temperature of 10 to $30^{\circ} \mathrm{C}$ [55].

Although there are reports detailing AF contamination in nuts of many countries, there are no reports on those of Mexico. The aims of the present study were to purify, identify and quantify the $A F\left(A_{1} B_{1}\right.$, $\mathrm{AFB}_{2}, \mathrm{AFG}_{1}$ and $\mathrm{AFG}_{2}$ ) in three types of nuts: the walnut, pecan and cashew from Mexico. Additionally, we aimed to: a) validate the AF HPLC quantification method for the three nuts, including defining the lineality, selectivity, recovery percentage, limit of detection, and limit of quantification; b) extract and purify the AF present in the three nuts; c) compare the AF content in the three nuts statistically; and d) determine whether the AF content of the three nuts is under the tolerable limit defined in Mexican legislation for AF in food.

\section{Materials and Methods}

\section{AF standards}

The AF standards $\left(\mathrm{AFB}_{1}, \mathrm{AFB}_{2}, \mathrm{AFG}_{1}\right.$ and $\left.\mathrm{AFG}_{2}\right)$ from SigmaAldrich (St. Louis MO, USA) were prepared as $1 \mu \mathrm{g} / \mathrm{mL}$ solutions [56], dissolved in a benzene: acetonitrile mixture $(98: 2 \mathrm{v} / \mathrm{v})$ and stored in amber vials at $4^{\circ} \mathrm{C}$. The $\mathrm{UV}$-Vis spectrophotometer (Genesys 10 UV-Vis, Thermo Electron Corporation, Madison, Wisconsin, USA) was calibrated for the correction factor (method 971.22B) [56], the absorbance was adjusted to 0 with a blank of benzene: acetonitrile $(98: 2 \% \mathrm{v} / \mathrm{v})$ and the wavelength of maximum absorbance for the four AF was determined.

\section{Sampling}

Fifty grams of each of the three types of nuts were sampled in the three biggest and most important markets of each one of the 16 boroughs of Mexico City. The samples of the same kind of nut from the three markets of each borough were mixed to make a compound sample that was ground and homogenized to obtain $51 \mathrm{~g}$ for the AF analysis (Table 1). There were two 50-g samples (walnut and cashew) purchased in 2012 from the Spices Market in Istanbul, Turkey.

\section{Chemical analysis}

A stock solution of $1 \mu \mathrm{g} / \mathrm{mL}$ each of $\mathrm{AFB}_{1}, \mathrm{~B}_{2}, \mathrm{G}_{1}$ and $\mathrm{G}_{2}$ was used to make 16 dilutions for the lineality validation assay.

One milliliter of benzene: acetonitrile $(98: 2 \% \mathrm{v} / \mathrm{v})$ was injected in a new AF standard vial. Afterwards, an unknown amount of AF standard 
Citation: Citation: Adaya-González, J, Carvajal-Moreno, M, Rojo-Callejas, F and Ruiz-Velasco, S.(2015) Aflatoxins in Walnut (Juglans regia L.), Pecan (Carya illinoinensis (Wangenh.) K. Koch) and Cashew (Anacardium occidentale L.) Nuts of Mexico. Pharm Anal Acta 6: 338. doi:10.4172/2153-2435.1000338

Page 3 of 10

\begin{tabular}{|c|c|c|c|}
\hline $\begin{array}{l}\text { Date in } \\
2012\end{array}$ & $\begin{array}{l}\text { Boroughs/inhabitants } \\
\text { in } 2010\end{array}$ & Markets & Nut type \\
\hline \multirow{3}{*}{ 30/ago } & \multirow{3}{*}{ Álvaro Obregón/ 727,034 } & Corpus Christi & \multirow{4}{*}{$\begin{array}{c}\text { Walnut, pecan and } \\
\text { cashew }\end{array}$} \\
\hline & & Olivar del Conde & \\
\hline & & Melchor Múzquiz & \\
\hline \multirow{3}{*}{ 19/sep } & \multirow{3}{*}{ Azcapotzalco/ 414,711 } & Azcapotzalco. & \\
\hline & & Prohogar. & Pecan and cashew \\
\hline & & Nueva Santa María. & \multirow{9}{*}{$\begin{array}{c}\text { Walnut, pecan and } \\
\text { cashew }\end{array}$} \\
\hline \multirow{3}{*}{ 30/ago } & \multirow{3}{*}{ Benito Juárez/ 385,439 } & Portales. & \\
\hline & & Mixcoac. & \\
\hline & & Independencia. & \\
\hline \multirow{3}{*}{ 29/ago } & \multirow{3}{*}{ Coyoacán/ 620,416 } & Coyoacán. & \\
\hline & & Ajusco-Moctezuma. & \\
\hline & & $\begin{array}{l}\text { Santo Domingo "Las } \\
\text { Rosas". }\end{array}$ & \\
\hline \multirow{3}{*}{ 13/sep } & \multirow{3}{*}{ Cuajimalpa/186,391 } & Rosas Torres. & \\
\hline & & Cuajimalpa. & \\
\hline & & Contadero. & Pecan. \\
\hline \multirow{3}{*}{$6 /$ sep } & \multirow{3}{*}{ Cuauhtémoc/ 531,831 } & Arcos de Belén. & \multirow{2}{*}{$\begin{array}{c}\text { Walnut, pecan and } \\
\text { cashew }\end{array}$} \\
\hline & & San Juan. & \\
\hline & & Hidalgo. & Pecan and cashew. \\
\hline \multirow{3}{*}{ 19/sep } & \multirow{3}{*}{$\begin{array}{c}\text { Gustavo A. Madero/ } \\
1,185,772\end{array}$} & Río Blanco. & Pecan \\
\hline & & La Estrella. & $\begin{array}{c}\text { Walnut, pecan and } \\
\text { cashew }\end{array}$ \\
\hline & & Martín Carrera. & \multirow{2}{*}{ Pecan and cashew } \\
\hline \multirow{3}{*}{ 26/sep } & \multirow{3}{*}{ Iztacalco/ 384,326 } & San Miguel Iztacalco. & \\
\hline & & Santa Anita. & \\
\hline & & Tlacotal & \\
\hline \multirow{3}{*}{$26 /$ sep } & \multirow{3}{*}{ Iztapalapa/1,815,786 } & Central de Abasto. & \\
\hline & & $\begin{array}{l}\text { Santa Cruz } \\
\text { Meyehualco. }\end{array}$ & $\begin{array}{c}\text { Walnut, pecan and } \\
\text { cashew }\end{array}$ \\
\hline & & Jacarandas. & \\
\hline & & Cerro del Judío. & \\
\hline 12/sen & La Magdalena & La Loma. & \\
\hline 4121000 & Contreras/ 239,086 & $\begin{array}{l}\text { Turístico La } \\
\text { Magdalena. }\end{array}$ & Pecan \\
\hline & & Tacubaya. & \\
\hline $12 /$ sep & Miguel Hidalgo/ 372,889 & $\begin{array}{l}\text { Plutarco Elías Calles, } \\
\text { "El Chorrito". }\end{array}$ & \\
\hline & & Argentina. & $\begin{array}{c}\text { Walnut, pecan and } \\
\text { cashew }\end{array}$ \\
\hline & & $\begin{array}{l}\text { San Antonio } \\
\text { Tecómitl. }\end{array}$ & \\
\hline 5/sep & Milpa Alta/ 130,582 & Benito Juárez. & \\
\hline & & San Pedro Atocpan. & Pecan and cashew \\
\hline & & Colonia del Mar. & $\begin{array}{c}\text { Walnut, pecan and } \\
\text { cashew }\end{array}$ \\
\hline 27/sep & Tláhuac/ 360,265 & La Nopalera. & \\
\hline & & Tláhuac. & \\
\hline & & Torres de Padierna. & \\
\hline $6 /$ sep & Tlalpan/ 650,567 & Tlalcoligia. & \\
\hline & & De la Luz & \\
\hline & & San Ciprián. & \\
\hline $20 /$ sep & $\begin{array}{c}\text { venustiano Carranzal } \\
430.978\end{array}$ & Jamaica. & \\
\hline & & La Merced. & \\
\hline & & Xochimilco. & \\
\hline $5 /$ sep & Xochimilco/ 415,007 & $\begin{array}{l}\text { San Gregorio } \\
\text { Atlapulco. }\end{array}$ & Walnut and cashew \\
\hline & & Tulyehualco & \\
\hline $5 /$ nov & Turkey & $\begin{array}{l}\text { Market of Spices } \\
\text { Istanbul, Turkey }\end{array}$ & Walnut and cashew \\
\hline
\end{tabular}

Table 1: The samples of the same kind of nut from the three markets of each borough were mixed to make a compound sample that was ground and homogenized to obtain $51 \mathrm{~g}$ for the AF analysis was placed in the vial, and it was diluted to one $\mathrm{mL}$ with HPLCgrade methanol $(\mathrm{MeOH})$; later, an unknown amount was placed in a quartz cell for the absorbance measurement in the spectrophotometer (Thermo Modelo Genesys $10 \mathrm{UV}$ ) at a wavelength of $362 \mathrm{~nm}$, and the concentration was calculated with the following formula [56]:

Conc $(\mu \mathrm{g} / \mathrm{mL})=$ Abs at $362 \mathrm{~nm} \times \mathrm{Mw} \times 1000 /$ Extinction coefficient where Conc $=$ concentration, $\mathrm{Abs}=$ Absorbance, $\mathrm{Mw}=$ molecular weight and $\mathrm{Ec}=$ extinction coefficient

Depending on the $\mathrm{AF}$, the molecular weight $(\mathrm{mw})$ and the extinction coefficient (ec) were: $\mathrm{AFB}_{1}(\mathrm{mw}=312$; ec $=21,800)$; $\mathrm{AFB} 2$ $(\mathrm{mw}=314 ; \mathrm{ec}=24,000) ; \mathrm{AFG} 1 \quad(\mathrm{mw}=328$ and $\mathrm{ec}=17,700)$ and AFG2 $(\mathrm{mw}=330 ; \mathrm{ec}=17,100)[56]$.

\section{Derivatization}

The dry AF standards were resuspended with $200 \mu \mathrm{l}$ acetonitrile $(\mathrm{ACN})$ and $800 \mu \mathrm{l}$ of derivatizing solution to increase fluorescence. The derivatizing solution consisted of $5 \mathrm{~mL}$ of trifluoroacetic acid (TFA) (Sigma-Aldrich, St. Louis MO, USA), with $2.5 \mathrm{~mL}$ of glacial acetic acid (Merck, Naucalpan, Edo. Mex., México) and $17.5 \mathrm{~mL}$ of deionized water to obtain a final concentration of $20 \%$ TFA (v/v); the mixture was vortexed (Vortex G-560, Bohemia, N.Y., EEUU) for 30 seconds.

The vials were placed in a water bath (Aparatos de Laboratorio BG Mod. BM 40T, Mexico) at $65^{\circ} \mathrm{C}$ for $10 \mathrm{~min}$ [57,58]. Following this period, they were injected into the HPLC for chemical quantification.

\section{AF extraction of the samples}

The walnut, pecan and cashew nuts were independently ground (Black and Decker Crush Master, Mod. V2350BP), and $50 \mathrm{~g}$ of each type of nut from the three markets in each borough were added together to make a 51-g compound sample. The compound samples were blended with $100 \mathrm{~mL}$ of a solution of methanol:distilled water $\left(\mathrm{H}_{2} \mathrm{O}_{\mathrm{d}}\right)(80: 20$ $\mathrm{v} / \mathrm{v})$ and $2 \mathrm{~g} \mathrm{NaCl}$ for $2 \mathrm{~min}$.

The samples were filtered through a Büchner funnel adapted to a vacuum pump, and $2 \mathrm{~mL}$ of the filtrate were diluted with $14 \mathrm{~mL}$ of phosphate-buffered saline (PBS) at $\mathrm{pH}$ 7.4. The diluted filtrate was passed through an immunoaffinity column (Easi-Extract Aflatoxin R-Biopharm Rhône, Ltd.) previously balanced with $20 \mathrm{~mL}$ of PBS $[59,60]$ for the detection of total AF (AFt). After receiving the sample filtrate, the immunoaffinity column was washed with $20 \mathrm{~mL}$ of $\mathrm{H}_{2} \mathrm{O}_{\mathrm{d}}$ at a flux of $5 \mathrm{~mL}$ per min. Air was passed through the agarose gel of the immunoaffinity column to dry it, and it received $1.5 \mathrm{~mL}$ of HPLCgrade $\mathrm{MeOH}$ by gravity at one drop per second. Afterwards, $1.5 \mathrm{~mL}$ of $\mathrm{H}_{2} \mathrm{O}_{\mathrm{d}}$ was applied to denature the gel with AFt antibodies and release the pure AF in the $3-\mathrm{mL}$ eluate. Finally, the eluate was dried at $40^{\circ} \mathrm{C}$, and it was derivatized as mentioned before.

\section{AF quantification by HPLC}

The standard AF HPLC analysis [61] and the eluting of samples were performed with an Agilent Technologies HPLC (Series 1200) with an isocratic pump (G1310A Series DE62957044), fluorescence detector (G1321A Series DE60456380) and autosampler (G1329A Series DE64761666), a chromatographic Agilent Eclipse XDS-C18 column $(4.6 \times 250 \mathrm{~mm}, 5 \mu \mathrm{m}$ of particle size $)$ and the HPLC program Chem Station 32. The analytical conditions were: $\mathrm{H}_{2} \mathrm{O} / \mathrm{ACN} / \mathrm{MeOH}$ (65:15:20 $\mathrm{v} / \mathrm{v} / \mathrm{v}$ ) mobile phase, $60-\mu \mathrm{L}$ injection volume, $1 \mathrm{~mL} / \mathrm{min}$ fluid speed for $20 \mathrm{~min}$, excitation at $362 \mathrm{~nm}$ and emission at 425 for $\mathrm{AFB}_{1}$ and $\mathrm{AFB}_{2}$ and $450 \mathrm{~nm}$ for $\mathrm{AFG}_{1}$ and $\mathrm{AFG}_{2}$. 
Citation: Citation: Adaya-González, J, Carvajal-Moreno, M, Rojo-Callejas, F and Ruiz-Velasco, S.(2015) Aflatoxins in Walnut (Juglans regia L.), Pecan (Carya illinoinensis (Wangenh.) K. Koch) and Cashew (Anacardium occidentale L.) Nuts of Mexico. Pharm Anal Acta 6: 338. doi:10.4172/2153-2435.1000338

Page 4 of 10

\section{Validation of the HPLC quantification method for AF in nuts}

Validation is the confirmation, with objective evidence, that the requirements for a certain application of the method have been realized [62]. The validation of the method was done in agreement with the EC Regulatory Commission 2004/882 that considers the following steps:

Selectivity: Selectivity is the degree to which the method can determine the analyte (AF) without matrix interference. A mixture of the $4 \mathrm{AF}$ standards was analyzed (blank), as well as the three matrices (walnut, pecan and cashew) independently enriched with the four AF. The blank and the three nut sources with AFs were extracted, purified with immunoaffinity total anti-aflatoxin columns, derivatized and the resulting chromatograms were compared.

Lineality: Lineality is the ability to obtain proportional results to the analyte (AF) concentration. Sixteen standard dilutions $(0.01,0.05$, $0.1,0.5,1,2,4,8,16,32,64,128,200,600,800$ and $1000 \mathrm{ng} / \mathrm{mL})$ of each of the four AF were tested separately to obtain the calibration curves and the limits of detection (LOD) and quantification (LOQ).

Limits of detection (LOD) and quantification (LOQ): The LOD was determined by observing the minimal concentration that displayed the chromatographic peak signal by HPLC. The LOQ was calculated taking into account the sample results, and it was calculated as the LOD per five.

Recovery percentage (R\%): The recovery percentage is the efficiency of the method to detect all of the analyte (AFs) present in a sample. Each matrix (walnut, pecan and cashew) was fortified with 100 $\mathrm{ng} / \mathrm{g}$ of each one of the four AF independently before the analysis. Later, the extraction and derivatization were performed, and the recovery percentage allowed for the adjustment of the AF concentrations in the samples. This validation method parameter is important to obtain the real results.

Statistical analysis: A non-parametric Kruskal-Wallis test, followed by a Wilcoxon range test, was conducted to determine which groups had the significant differences in quantity and nut type of the samples composed from nuts from three markets in each borough of Mexico City and the Turkey samples.

\section{Results and Discussion}

\section{Validation of the method to quantify AF in nuts}

Selectivity: The chromatograms after the AF addition the three matrices showed that the elution order of the analytes and the retention times (rt) were not modified by the different nut matrices, and the four AF analytes did not overlap (Figure 2).

Lineality and limits of detection (LOD) and quantification (LOQ): The standard solutions that had positive results were: $\mathrm{AFB}_{1}$ $(0.1,0.5,1,2,4,8,16,32,64$ and $128 \mathrm{ng} / \mathrm{mL}), \mathrm{AFB}_{2}(0.01,0.05,1,5$, $10,20,40,70,100$ and $200 \mathrm{ng} / \mathrm{mL}), \mathrm{AFG}_{1}(0.01,0.05,0.1,0.5,1,4,16$, 100 and $128 \mathrm{ng} / \mathrm{mL})$ and $\mathrm{AFG}_{2}(0.5,1,2,4,8,16,32,64,100,200,600$, 800 and $100 \mathrm{ng} / \mathrm{mL}$ ). The parameters of the AF calibration curves (LOD and LOQ) were: for AFB, slope $=2.8299$, correlation coefficient $\left(\mathrm{R}^{2}\right)$ of $0.9973, \mathrm{n}=28, \mathrm{LOD}=0.1 \mathrm{ng} / \mathrm{mL}$, and $\mathrm{LOQ}=1 \mathrm{ng} / \mathrm{mL} ; \mathrm{AFB}_{2}$, slope $=1.7786, \mathrm{R}^{2} 0.9908, \mathrm{n}=38, \mathrm{LOD}=0.01 \mathrm{ng} / \mathrm{mL}$ and $\mathrm{LOQ}=0.1 \mathrm{ng} /$ $\mathrm{mL} ; \mathrm{AFG}_{1}$, slope $=1.7607, \mathrm{R}^{2}=0.9969, \mathrm{n}=26, \mathrm{LOD}=0.01$ and $\mathrm{LOQ}=0.1$ $\mathrm{ng} / \mathrm{mL}$ and $\mathrm{AFG}_{2}$, slope $=1.247, \mathrm{R}^{2}=0.9908, \mathrm{n}=38, \mathrm{LOD}=0.5 \mathrm{ng} / \mathrm{mL}$ and $\mathrm{LOQ}=5 \mathrm{ng} / \mathrm{mL}$. The LOD results were very good, the equipment detected low levels of AF that made the quantification accurate.

\section{Retention times (RT) and recovery percentage (R\%)}

The retention times were adjusted according to the selectivity, lineality and recovery percentage for each type of nut.

For the walnut, the following were obtained: $\mathrm{AFB}_{1}, \mathrm{RT}=7.709$ $9.478 \mathrm{~min}$ and $\mathrm{R} \%=88.12 \pm 2.31 ; \mathrm{AFB}_{2}, \mathrm{RT}=17.590-19.804 \mathrm{~min}$ and $\mathrm{R} \%=95.16 \pm 0.59 ; \mathrm{AFG}_{1}, \mathrm{RT}=5.642-6.447 \mathrm{~min}$ and $\mathrm{R} \%=82.92 \pm 2.58$; $\mathrm{AFG}_{2}, \mathrm{RT}=11.319-13.247 \mathrm{~min}$ and $\mathrm{R} \%=82.01 \pm 3.13$.

For the pecan, the following were obtained: $\mathrm{AFB}_{1}, \mathrm{RT}=7.709-9.478$ min and $\mathrm{R} \%=85.17 \pm 1.85 ; \mathrm{AFB}_{2}, \mathrm{RT}=17.590-19.804 \mathrm{~min}$ and $\mathrm{R} \%=$ 86.89 $\pm 13.66 ; \mathrm{AFG}_{1}, \mathrm{RT}=5.642-6.447 \mathrm{~min}$ and $\mathrm{R} \%=75.24 \pm 9.35 ; \mathrm{AFG}_{2}$, $\mathrm{RT}=11.319-13.247 \mathrm{~min}$ and $\mathrm{R} \%=85.92 \pm 3.49$.

For the cashew, the following were obtained: $\mathrm{AFB}_{1}, \mathrm{RT}=7.709$ - $9.478 \mathrm{~min}$ and $\mathrm{R} \%=84.15 \pm 0.9 ; \mathrm{AFB}, \mathrm{RT}=17.590-19.804 \mathrm{~min}$ and $\mathrm{R} \%$ 87.31 $\pm 6.03 ; \mathrm{AFG}_{1}, \mathrm{RT}=5.642-6.447 \mathrm{~min}$ and $\mathrm{R} \%=86.11 \pm 3.55$ and $\mathrm{AFG}_{2}, \mathrm{RT}=11.319-13.247 \mathrm{~min}$ and $\mathrm{R} \%=86.33 \pm 4.75$ (Figure 3A).

The three nut recovery percentages were from $75.24 \%$ to $95.16 \%$ that are excellent recoveries from natural products. These results validated the AF percentage of recovery of the three nuts.

\section{AF quantification of nut samples by HPLC}

A total of 50 samples were analyzed, of which $22 \%(11 / 50)$ were contaminated with $\mathrm{AFB}_{1}$, and $100 \%$, with $\mathrm{AFt}$. Of the walnut samples, $35.30 \%(6 / 17)$ had $\mathrm{AFB}_{1}$ contamination, while $17.65 \%$ of the cashew samples (3/17) and $12.50 \%$ of the pecan samples $(2 / 16)$ were contaminated with $\mathrm{AFB}_{1}$. Four of the five most contaminated samples were walnuts from the center-south boroughs, such as Coyoacan $(0.16$ $\mathrm{ng} / \mathrm{g})$, Tlalpan $(0.23 \mathrm{ng} / \mathrm{g})$, Tlahuac $(0.10 \mathrm{ng} / \mathrm{g})$ and Xochimilco $(0.15$ $\mathrm{ng} / \mathrm{g})$, as shown in Table 2 .

$\mathrm{AFB}_{1}$ contamination was present in pecan samples from the Álvaro Obregón $(0.08 \mathrm{ng} / \mathrm{g})$ and La Magdalena Contreras $(0.06 \mathrm{ng} / \mathrm{g})$ boroughs, which are geographically close; walnut and cashew samples from this area were not contaminated. The three $\mathrm{AFB}_{1}$ contaminated cashew samples had no geographical relation (Tláhuac, $0.17 \mathrm{ng} / \mathrm{g}$, Tlalpan, $0.07 \mathrm{ng} / \mathrm{g}$ and Venustiano Carranza, $0.07 \mathrm{ng} / \mathrm{g}$ ), and these boroughs also had high $\mathrm{AFB}_{1}$ in the walnut (Figure 3).

All of the boroughs had AFt contamination, and the walnut was the most affected type of nut, with the Turkey samples $(12.10 \mathrm{ng} / \mathrm{g})$ and those from Iztacalco $(7.92 \mathrm{ng} / \mathrm{g})$ being the most contaminated ones, followed by cashew samples from Milpa Alta $(6.89 \mathrm{ng} / \mathrm{g})$. The boroughs with $\mathrm{AFB}_{1}$ contamination were not the same as the ones with high $\mathrm{AFt}$, due to the AFt values that were heavily affected by the high $\mathrm{AFG}_{2}$ values (Figure 3).

The percentages of $\mathrm{AFB}_{1}$ and $\mathrm{AFt}$ in the samples from Mexico City were $35.30 \%$ for the walnut, $17.65 \%$ for the cashew, and $12.50 \%$ for the pecan. In comparison the AFt contamination percentage in the City of Mekkah was higher, $50 \%$ in walnuts and $15 \%$ in cashews [63], and in Malaysia a lower frequency was found, $16.3 \%$ AFt contamination (17.2 to $350 \mu \mathrm{g} / \mathrm{kg}$ ) [64]. Poland had walnuts that were $38 \%$ contaminated, with $5.50 \mu \mathrm{g} / \mathrm{kg} \mathrm{AFt}$ and $4.04 \mu \mathrm{g} / \mathrm{kg} \mathrm{AFB}$, and cashews with $0.35 \mu \mathrm{g} /$

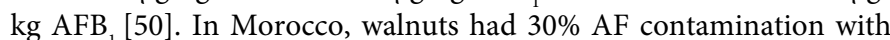
a sample that included $2500 \mathrm{~g} / \mathrm{kg}$ of $\mathrm{AFB}_{1}$ [47], and in Pakistan, the walnut contamination was $40 \%$ with the shell intact and $70 \%$ in a shelled nut [48].

Toxigenic A. flavus strains produce only $\mathrm{AFB}_{1}$ and $\mathrm{AFB}_{2}$, and $A$. parasiticus produce the four $\mathrm{AF}, \mathrm{AFB}_{1}, \mathrm{AFB}_{2}, \mathrm{AFG}_{1}$ and $\mathrm{AFG}_{2}[65,66]$ 
Citation: Citation: Adaya-González, J, Carvajal-Moreno, M, Rojo-Callejas, F and Ruiz-Velasco, S.(2015) Aflatoxins in Walnut (Juglans regia L.), Pecan (Carya illinoinensis (Wangenh.) K. Koch) and Cashew (Anacardium occidentale L.) Nuts of Mexico. Pharm Anal Acta 6: 338. doi:10.4172/2153-2435.1000338

Page 5 of 10

In the analyzed samples of Mexico City, all four AF were found, so the conclusion is that the nuts were invaded by both $A$. flavus and $A$. parasiticus, and the $\mathrm{pH}$ conditions determined the type of metabolites synthesized by the mold: $\mathrm{pH}$ values below 6 favored $\mathrm{AF}$ type $\mathrm{B}$, and $\mathrm{pH}$ values above 6 , in the case of nuts, stimulate the synthesis of AF from group $G$ [67], which would explain the high values of $A_{F} G_{2}$ found in the samples (Figure 3).

Although $\mathrm{AFB}_{1}$ and $\mathrm{AFG}_{1}$ are more toxic than $\mathrm{AFB}_{2}$ and $\mathrm{AFG}_{2}$ [68], the latter two can oxidize in vivo to $\mathrm{AFB}_{1}$ and $\mathrm{AFG}_{1}$, respectively [69]. The obtained AFt averages for the walnut $(2.7 \mu \mathrm{g} / \mathrm{kg})$, pecan $(0.4$ $\mu \mathrm{g} / \mathrm{kg})$ and cashew $(1.4 \mu \mathrm{g} / \mathrm{kg})$ are in agreement with the European Commission Rules and the NMX-FF-093-SCFI-2011 Rule that establish a legal limit of $10 \mu \mathrm{g} / \mathrm{kg}$ and are below the tolerance limit and acceptable for exportation [70].

$\mathrm{AF}$ were analyzed at a ng/g level, but the amount that a person consumes in cooked food and desserts exceeds tolerance limits, and depending on the frequency, can be considered a risk for chronic health effects. The total AF calculation from nut ingestion in different commercial presentations exceeds $10 \mu \mathrm{g} / \mathrm{kg}$, the amount needed to produce a mutation in cells; therefore, a carcinogenic risk persists. Taking into account the AFt (ng/g) average of the walnut (2.7), the calculation in cooked food per consumption was: 1 ) of $46.25 \mathrm{~g}$ of walnut sauce ("nogada") for stuffed chiles would be $125 \mathrm{ng}$ AFt; and 2) one kg of walnuts $=2700 \mathrm{ng} \mathrm{AFt}$. With respect to the cashew, the average was $1.4 \mathrm{ng} / \mathrm{g} \mathrm{Aft}$, so a package of $40 \mathrm{~g}$ would be $56 \mathrm{ng}$, and a package of 250 $\mathrm{g}$ would be $350 \mathrm{ng}$ AFt. Finally, the AFt average for the pecan was 0.4 $\mathrm{ng} / \mathrm{g}$, so a package of $100 \mathrm{~g}$ would equal $44 \mathrm{ng} / \mathrm{g} \mathrm{AFt}$ and a package of $250 \mathrm{~g}$ would equal $110 \mathrm{ng} / \mathrm{g}$ AFt. Two hundred and fifty grams of pecan cookies would equal $110 \mathrm{ng} / \mathrm{g}$, a 375-g slice of pecan cake would equal

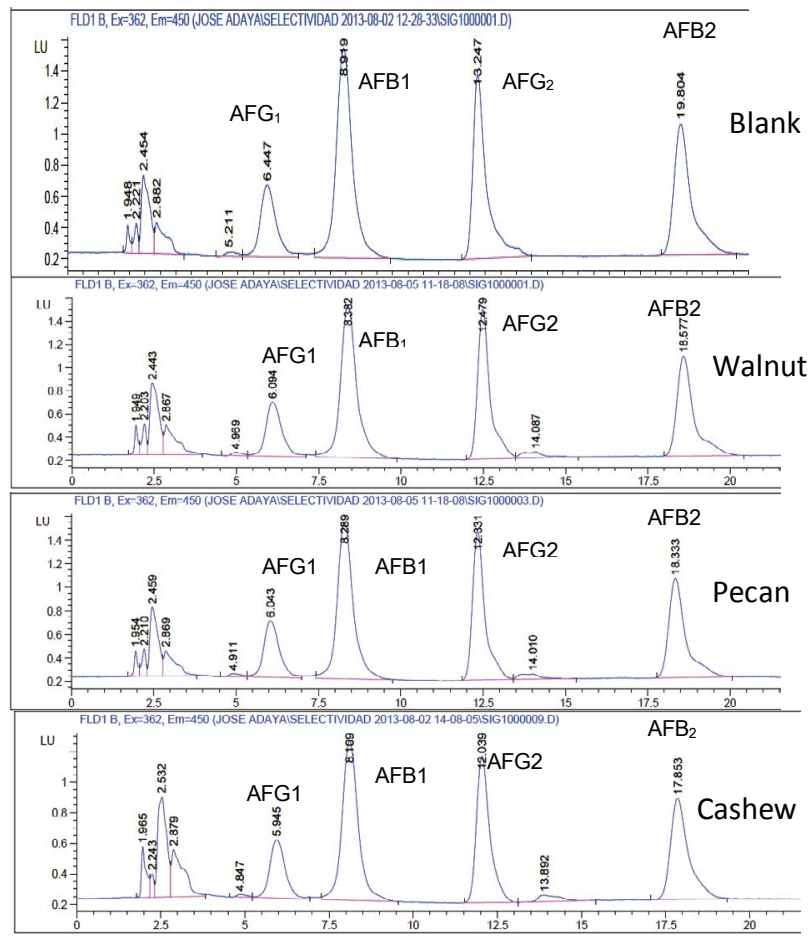

Figure 2: Chromatograms obtained from the selectivity assay with the 4 Aflatoxins: 1) Blank only with the Aflatoxin standards; 2) AF in walnut; 3) AF in pecan and 4) AF in cashew.
$150 \mathrm{ng} / \mathrm{g} \mathrm{AFt}$, and $50 \mathrm{~g}$ of pecan ice cream would equal $20 \mathrm{ng} / \mathrm{g}$ AFt.

Nuts are part of a healthy diet against diabetes [13] because they contains antioxidants, unsaturated fatty acids, and vitamins, according to reports on the walnut [71]. Additionally, pecans contain compounds that have protective effects on the heart [72], and cashews contain cardol, which has antimicrobial activities [73].

The walnut is an important crop for the food industry, as a nutriment, and for the health benefit it provides due to its oils, proteins, minerals, flavonoids, phenolic acids (antioxidants), polyphenols and vitamins [71]. Nut antioxidants help protect against fat nodules (atheroma plaques) in the arteries, are anti-inflammatory and antimutagenic [74].

The pecan is a source of monounsaturated fatty acids and heartprotective compounds, including vegeTable sterols, vitamins A, B and E, folic acid, calcium, magnesium, phosphorus, zinc and fiber [72]. It is a food that is free of cholesterol with a high protein content, and its oleic acid is similar to that in olives [75].

The cashew has more ascorbic acid than oranges, vitamins $B_{1}$, $B_{2}$, pantothenic acid, and minerals, such as magnesium [76], and it is rich in unsaturated fatty acids, such as oleic and linoleic acids. The cashew has raw protein and lysine comparable to peanuts [77] and the soybean, and it has higher sulfur amino acids, and oils and gums with cardol, which is a caustic and poisonous substance that evaporates when the nuts are heated [78]. The cashew contains a group of phenolic compounds known as "cashew nut shell liquid" (CNSL) $[79,80]$ that includes anacardic acid, cardanol and cardol, this last of which has been reported to have antimicrobial activities [73], possibly giving resistance to Aspergillus invasion.

All of the samples contained the AF carcinogens. In the millions of years of co-existing together, it seems that as a reaction to mold and its aflatoxins, nut trees have developed high amounts of resistance $[81,82]$ and antioxidant phytochemicals [83] such as caffeic acid, which reduces the AFs by $99.5 \%$, quinic acid $(90.2 \%)$ and chlorogenic acid (88.5\%) [84]. Therefore, beneficial components, such as antioxidants, and dangerous toxins appear together.

\section{Statistical Analysis}

The Kruskal-Wallis test with the Statistical Program R showed that the walnut had significant differences among the boroughs for $\mathrm{AFB}_{1}, \mathrm{AFB}_{2}$ and $\mathrm{AFG}_{1}$ For the pecan and cashew, significant differences were only found among the boroughs for $\mathrm{AFB}_{2}$ and $\mathrm{AFG}_{1}$ content; no differences for $\mathrm{AFG}_{2}$ and $\mathrm{Aft}$ were observed (Table 3).

With respect to the type of nut as a variation source, there were significant differences for the four AF and AFt. The results of the Kruskal-Wallis statistical values were: $\mathrm{AFB}_{1}=9.24, \mathrm{AFB}_{2}=8.03$, $\mathrm{AFG}_{1}=62.57 ; \mathrm{AFG}_{2}=17.24$ and $\mathrm{AFt}=40.31$, all displaying significance levels $<0.05$.

Figure 4 gives the $\mathrm{AFB}_{1}$ results from the Wilcoxon test, which was used to find significant differences among the groups. The walnut samples from the Tlalpan and Coyoacan boroughs were the most contaminated with $\mathrm{AFB}_{1}$ and were significantly different $(\mathrm{p}<0.05)$ from the other boroughs, while there were no significant differences between the source (or location) for $\mathrm{AFB}_{1}$ in pecans and cashews. In the case of $\mathrm{Aft}$, there was not a significant difference when considering borough as the variation factor.

The walnut was the most contaminated nut for $\mathrm{AFB}_{1}(0.04 \mathrm{ng} / \mathrm{g}$, 
Citation: Citation: Adaya-González, J, Carvajal-Moreno, M, Rojo-Callejas, F and Ruiz-Velasco, S.(2015) Aflatoxins in Walnut (Juglans regia L.), Pecan (Carya illinoinensis (Wangenh.) K. Koch) and Cashew (Anacardium occidentale L.) Nuts of Mexico. Pharm Anal Acta 6: 338. doi:10.4172/2153-2435.1000338

Page 6 of 10

\begin{tabular}{|c|c|c|c|c|c|c|c|c|c|c|c|}
\hline \multirow{2}{*}{ Nut type } & \multirow{2}{*}{ Borough } & \multicolumn{2}{|c|}{$\mathrm{AFB}_{1}$} & \multicolumn{2}{|c|}{$\mathrm{AFB}_{2}$} & \multicolumn{2}{|c|}{$\mathrm{AFG}_{1}$} & \multicolumn{2}{|c|}{$\mathrm{AFG}_{2}$} & \multicolumn{2}{|c|}{$\mathrm{AF}_{\mathrm{T}}$} \\
\hline & & $\varnothing$ & SD & $\varnothing$ & SD & $\varnothing$ & SD & $\varnothing$ & SD & $\varnothing$ & SD \\
\hline \multirow{17}{*}{ Walnut } & Álvaro Obregón & $<L O D$ & 0.00 & 0.04 & 0.01 & 0.14 & 0.05 & $<\mathrm{LOD}$ & 0.00 & 0.18 & 0.04 \\
\hline & Azcapotzalco & $<L O D$ & 0.00 & 0.03 & 0.02 & 0.26 & 0.17 & 2.04 & 1.77 & 2.33 & 1.65 \\
\hline & Benito Juárez & $<L O D$ & 0.00 & 0.16 & 0.06 & 0.10 & 0.02 & 1.75 & 1.01 & 2.01 & 0.98 \\
\hline & Coyoacán & 0.16 & 0.02 & 0.62 & 0.79 & 0.29 & 0.26 & 1.08 & 1.05 & 2.15 & 1.05 \\
\hline & Cuajimalpa & $<L O D$ & 0.00 & 0.07 & 0.07 & 0.19 & 0.10 & 0.63 & 0.05 & 0.89 & 0.13 \\
\hline & Cuauhtémoc & $<L O D$ & 0.00 & 0.04 & 0.01 & 0.05 & 0.03 & 0.70 & 0.61 & 0.80 & 0.62 \\
\hline & G.A. Madero & $<L O D$ & 0.00 & 0.04 & 0.02 & 0.32 & 0.07 & 1.31 & 1.15 & 1.67 & 1.20 \\
\hline & Iztacalco & $<L O D$ & 0.00 & 0.05 & 0.01 & 0.22 & 0.05 & 7.65 & 6.63 & 7.92 & 6.67 \\
\hline & Iztapalapa & $<L O D$ & 0.00 & 0.04 & 0.01 & 0.26 & 0.01 & 2.13 & 1.92 & 2.43 & 1.92 \\
\hline & La M. Contreras & $<L O D$ & 0.00 & 0.03 & 0.00 & 0.28 & 0.07 & 0.36 & 0.63 & 0.67 & 0.58 \\
\hline & Miguel Hidalgo & 0.03 & 0.06 & 0.04 & 0.01 & 0.38 & 0.03 & 0.86 & 0.99 & 1.32 & 0.94 \\
\hline & Milpa Alta & $<$ LOD & 0.00 & 0.28 & 0.36 & 0.13 & 0.02 & $<$ LOD & 0.00 & 0.41 & 0.37 \\
\hline & Tláhuac & 0.10 & 0.18 & 0.07 & 0.00 & 0.61 & 0.12 & 0.79 & 0.68 & 1.46 & 0.57 \\
\hline & Tlalpan & 0.23 & 0.25 & 0.06 & 0.02 & 2.20 & 0.67 & $<$ LOD & 0.00 & 2.50 & 0.80 \\
\hline & V. Carranza & 0.07 & 0.06 & 0.08 & 0.04 & 0.35 & 0.05 & 0.84 & 0.73 & 1.34 & 0.79 \\
\hline & Xochimilco & 0.15 & 0.05 & 0.55 & 0.05 & 0.51 & 0.11 & 4.29 & 2.56 & 5.50 & 2.55 \\
\hline & Turkey & $<L O D$ & 0.00 & 0.04 & 0.01 & 0.37 & 0.06 & 11.69 & 10.29 & 12.10 & 10.36 \\
\hline \multirow{16}{*}{ Pecan } & Álvaro Obregón & 0.08 & 0.07 & 0.16 & 0.19 & 0.92 & 0.04 & 0.13 & 0.12 & 1.30 & 0.32 \\
\hline & Azcapotzalco & $<L O D$ & 0.00 & 0.03 & 0.01 & 0.04 & 0.00 & 0.23 & 0.20 & 0.30 & 0.20 \\
\hline & Benito Juárez & $<L O D$ & 0.00 & 0.05 & 0.02 & 0.05 & 0.02 & 0.17 & 0.17 & 0.27 & 0.17 \\
\hline & Coyoacán & $<L O D$ & 0.00 & 0.03 & 0.00 & 0.03 & 0.01 & 0.17 & 0.14 & 0.23 & 0.15 \\
\hline & Cuajimalpa & $<L O D$ & 0.00 & 0.18 & 0.14 & 0.02 & 0.00 & 0.12 & 0.12 & 0.32 & 0.19 \\
\hline & Cuauhtémoc & $<L O D$ & 0.00 & 0.06 & 0.02 & 0.03 & 0.01 & 0.23 & 0.21 & 0.32 & 0.22 \\
\hline & G.A. Madero & $<L O D$ & 0.00 & 0.09 & 0.04 & 0.06 & 0.02 & 0.18 & 0.15 & 0.33 & 0.13 \\
\hline & Iztacalco & $<L O D$ & 0.00 & 0.12 & 0.04 & 0.04 & 0.01 & 0.72 & 0.16 & 0.88 & 0.19 \\
\hline & Iztapalapa & $<L O D$ & 0.00 & 0.04 & 0.01 & 0.02 & 0.00 & 0.25 & 0.22 & 0.31 & 0.22 \\
\hline & La M. Contreras & 0.06 & 0.10 & 0.12 & 0.16 & 0.18 & 0.25 & 0.28 & 0.36 & 0.64 & 0.87 \\
\hline & Miguel Hidalgo & $<L O D$ & 0.00 & 0.07 & 0.03 & 0.07 & 0.03 & 0.17 & 0.17 & 0.32 & 0.18 \\
\hline & Milpa Alta & $<$ LOD & 0.00 & 0.02 & 0.00 & 0.13 & 0.03 & 0.22 & 0.19 & 0.37 & 0.17 \\
\hline & Tláhuac & $<$ LOD & 0.00 & 0.09 & 0.04 & 0.07 & 0.02 & 0.20 & 0.17 & 0.35 & 0.20 \\
\hline & Tlalpan & $<L O D$ & 0.00 & 0.08 & 0.02 & 0.09 & 0.01 & 0.20 & 0.18 & 0.37 & 0.16 \\
\hline & V. Carranza & $<$ LOD & 0.00 & 0.12 & 0.02 & 0.10 & 0.02 & 0.16 & 0.14 & 0.38 & 0.11 \\
\hline & Xochimilco & $<$ LOD & 0.00 & 0.11 & 0.05 & 0.12 & 0.01 & 0.19 & 0.16 & 0.42 & 0.21 \\
\hline \multirow{17}{*}{ Cashew } & Álvaro Obregón & $<L O D$ & 0.00 & 0.05 & 0.02 & 0.03 & 0.01 & 0.16 & 0.28 & 0.23 & 0.27 \\
\hline & Azcapotzalco & $<L O D$ & 0.00 & 0.02 & 0.00 & 0.04 & 0.01 & 1.50 & 2.60 & 1.56 & 2.59 \\
\hline & Benito Juárez & $<$ LOD & 0.00 & 0.03 & 0.02 & 0.05 & 0.02 & 1.51 & 2.62 & 1.59 & 2.60 \\
\hline & Coyoacán & $<L O D$ & 0.00 & 0.03 & 0.01 & 0.02 & 0.01 & $<$ LOD & 0.00 & 0.05 & 0.01 \\
\hline & Cuajimalpa & $<L O D$ & 0.00 & 0.06 & 0.02 & 0.06 & 0.01 & 0.46 & 0.80 & 0.58 & 0.81 \\
\hline & Cuauhtémoc & $<$ LOD & 0.00 & 0.05 & 0.02 & 0.02 & 0.00 & 0.72 & 1.25 & 0.79 & 1.23 \\
\hline & G.A. Madero & $<L O D$ & 0.00 & 0.05 & 0.01 & 0.03 & 0.02 & 3.99 & 6.92 & 4.08 & 6.93 \\
\hline & Iztacalco & $<L O D$ & 0.00 & 0.04 & 0.00 & 0.04 & 0.01 & $<\mathrm{LOD}$ & 0.00 & 0.08 & 0.01 \\
\hline & Iztapalapa & $<$ LOD & 0.00 & 0.03 & 0.00 & 0.05 & 0.01 & 0.28 & 0.49 & 0.36 & 0.49 \\
\hline & La M. Contreras & $<$ LOD & 0.00 & 0.04 & 0.02 & 0.09 & 0.02 & 1.18 & 2.04 & 1.31 & 2.05 \\
\hline & Miguel Hidalgo & $<L O D$ & 0.00 & 0.08 & 0.10 & 0.08 & 0.03 & $<\mathrm{LOD}$ & 0.00 & 0.16 & 0.07 \\
\hline & Milpa Alta & $<L O D$ & 0.00 & 0.03 & 0.01 & 0.11 & 0.02 & 6.75 & 11.69 & 6.89 & 11.71 \\
\hline & Tláhuac & 0.17 & 0.30 & 0.08 & 0.03 & 0.10 & 0.01 & $<$ LOD & 0.00 & 0.35 & 0.29 \\
\hline & Tlalpan & 0.07 & 0.12 & 0.04 & 0.00 & 0.09 & 0.02 & $<\mathrm{LOD}$ & 0.00 & 0.20 & 0.12 \\
\hline & V. Carranza & 0.07 & 0.11 & 0.09 & 0.03 & 0.06 & 0.01 & 3.30 & 5.72 & 3.51 & 5.82 \\
\hline & Xochimilco & $<L O D$ & 0.00 & 0.09 & 0.04 & 0.06 & 0.00 & 1.10 & 1.91 & 1.25 & 1.88 \\
\hline & Turkey & $<L O D$ & 0.00 & 0.02 & 0.01 & 0.12 & 0.02 & $<$ LOD & 0.00 & 0.14 & 0.03 \\
\hline
\end{tabular}

Table 2. Aflatoxin concentration in samples, adjusted with the recovery percentage $(\mathrm{ng} / \mathrm{g})$.

$\mathrm{AF}=$ Aflatoxins, Aflatoxin B1 = AFB1, Aflatoxin B2 = AFB2, Aflatoxin G1 = AFG1, Aflatoxin G2 = AFG2 and Total Aflatoxins = AFt

Figure 5), followed by the cashew $(0.02 \mathrm{ng} / \mathrm{g})$ and the pecan $(0.01 \mathrm{ng} / \mathrm{g})$, with no significant difference between them, but with a direct relation with tannin content that are also a protection for the plant and have an indirect proportion with AF amount [85]. With respect to Aft, there was a significant difference among the three types of nuts, with the walnut being the most affected $(2.10 \mathrm{ng} / \mathrm{g})$, followed by the cashew $(1.36 \mathrm{ng} / \mathrm{g})$ and the pecan $(0.44 \mathrm{ng} / \mathrm{g})$. These results are in agreement with other reports $[50,63,86,87]$ of the walnut being more contaminated by $\mathrm{AFB}_{1}$ and AFt than the cashew.

The average $\mathrm{AFB}_{1}$ contamination in the three nuts was $0.024 \mathrm{ng} / \mathrm{g}$, and the average AFt was $1.30 \mathrm{ng} / \mathrm{g}$. Taking into account that $1.8 \mathrm{~kg}$ is the annual consumption by a person in Mexico City, Mexicans living 
Citation: Citation: Adaya-González, J, Carvajal-Moreno, M, Rojo-Callejas, F and Ruiz-Velasco, S.(2015) Aflatoxins in Walnut (Juglans regia L.), Pecan (Carya illinoinensis (Wangenh.) K. Koch) and Cashew (Anacardium occidentale L.) Nuts of Mexico. Pharm Anal Acta 6: 338. doi:10.4172/2153-2435.1000338

Page 7 of 10

A)

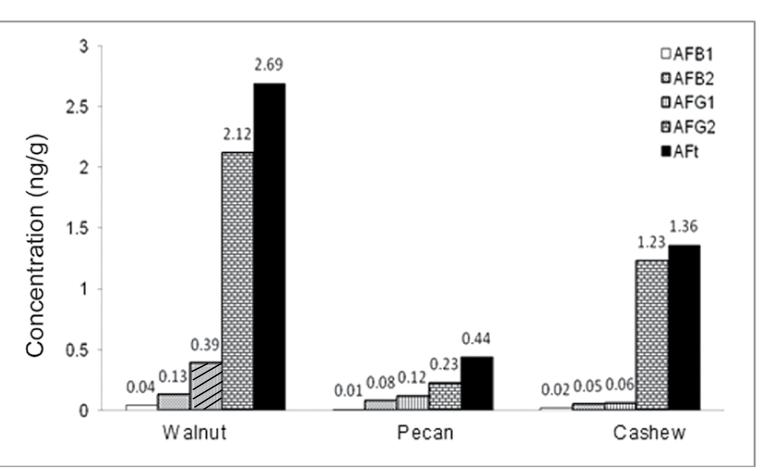

B)

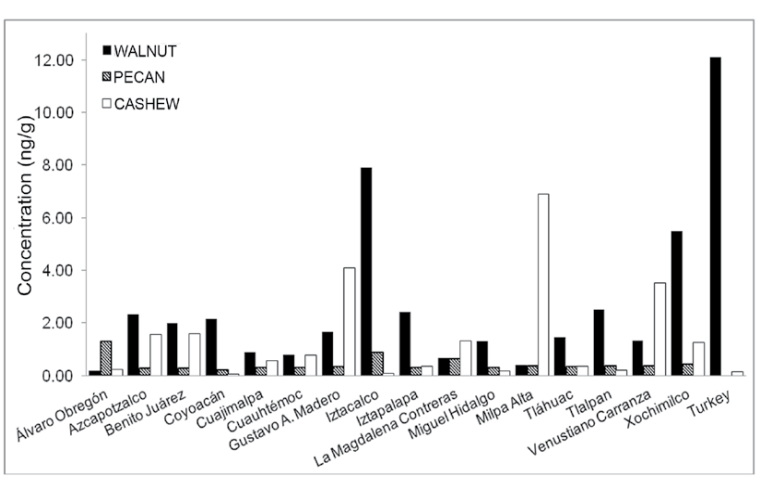

Figure 3: A) Average concentration of the four Aflatoxins $\left(\mathrm{AFB}_{1}, \mathrm{AFB}_{2}, \mathrm{AFG}_{1}\right.$, $A F G_{2}$ ) and total aflatoxin (AFt) in walnut, pecan and cashew in Mexico City. B) Average concentration of AFt in samples from the boroughs of Mexico City and Turkey.

\begin{tabular}{|c|c|c|c|c|}
\hline Nut type & Aflatoxin & $\begin{array}{c}\text { Kruskal-Wallis } \\
\text { statistical value }\end{array}$ & Significance & $\begin{array}{c}\text { Significant } \\
\text { difference }\end{array}$ \\
\hline \multirow{4}{*}{ Walnut } & $\mathrm{AFB}_{1}$ & 34.90 & $<0.05$ & Yes \\
\cline { 2 - 5 } & $\mathrm{AFB}_{2}$ & 27.41 & $<0.05$ & Yes \\
\cline { 2 - 5 } & $\mathrm{AFG}_{1}$ & 39.34 & $<0.05$ & Yes \\
\cline { 2 - 5 } & $\mathrm{AFG}_{2}$ & 21.50 & 0.16 & No \\
\cline { 2 - 5 } & $\mathrm{AFt}$ & 24.35 & 0.08 & No \\
\hline \multirow{5}{*}{ Pecan } & $\mathrm{AFB}_{1}$ & 24.24 & 0.06 & No \\
\cline { 2 - 5 } & $\mathrm{AFB}_{2}$ & 31.84 & $<0.05$ & Yes \\
\cline { 2 - 5 } & $\mathrm{AFG}_{1}$ & 38.48 & $<0.05$ & Yes \\
\cline { 2 - 5 } & $\mathrm{AFG}_{2}$ & 12.61 & 0.63 & No \\
\cline { 2 - 5 } & $\mathrm{AFt}$ & 18.86 & 0.22 & No \\
\hline \multirow{5}{*}{ Cashew } & $\mathrm{AFB}_{1}$ & 14.59 & 0.56 & No \\
\cline { 2 - 5 } & $\mathrm{AFB}_{2}$ & 31.38 & $<0.05$ & Yes \\
\cline { 2 - 5 } & $\mathrm{AFG}_{1}$ & 42.80 & $<0.05$ & Yes \\
\cline { 2 - 5 } & $\mathrm{AFG}_{2}$ & 7.68 & 0.96 & No \\
\cline { 2 - 5 } & $\mathrm{AFt}$ & 17.97 & 0.33 & No \\
\hline
\end{tabular}

Table 3. Kruskal-Wallis test applied to find significant differences between source boroughs of the samples.

in Mexico City consume $24 \mathrm{ng}$ of $\mathrm{AFB}_{1}$ and 1,300 ng of AFt only by nut ingestion per year, and this amount of carcinogens increases with the AF contribution of the other foods.

$\mathrm{AF}$ are regulated in more than 75 countries [88]. The world tolerance limits for $\mathrm{AFB}_{1}$ are 1 to $20 \mu \mathrm{g} / \mathrm{kg}$ and 0 to $35 \mu \mathrm{g} / \mathrm{kg}$ for $\mathrm{AFt}$ [89].

The World Health Organization (WHO) established a maximum tolerance limit of $5 \mu \mathrm{g} / \mathrm{kg}$ for $\mathrm{AFB}_{1}$ and $10 \mu \mathrm{g} / \mathrm{kg}$ for AFt in several foods [90]. The European Commission established an $\mathrm{AFB}_{1}$ limit of 2 $\mu \mathrm{g} / \mathrm{kg}$ and an AFt limit of $4 \mu \mathrm{g} / \mathrm{kg}$ for nuts, dry fruits and cereals in 1998 [70,91]. In Mexico, the Official Mexican Law regulates AF only in maize $(20 \mu \mathrm{g} / \mathrm{kg}$ of AFt). The NMX-FF-093-SCFI-2011 law is not compulsory and establishes a maximum tolerance limit of $10 \mu \mathrm{g} / \mathrm{kg}$ [92].

About the lethal dose we can take into account an outbreak in humans occurred in India in 1974, when almost 400 people became ill with fever and jaundice after eating maize contaminated with between 0.25 and $15 \mathrm{mg} / \mathrm{kg}$ aflatoxin and more than 100 died [93]. The median

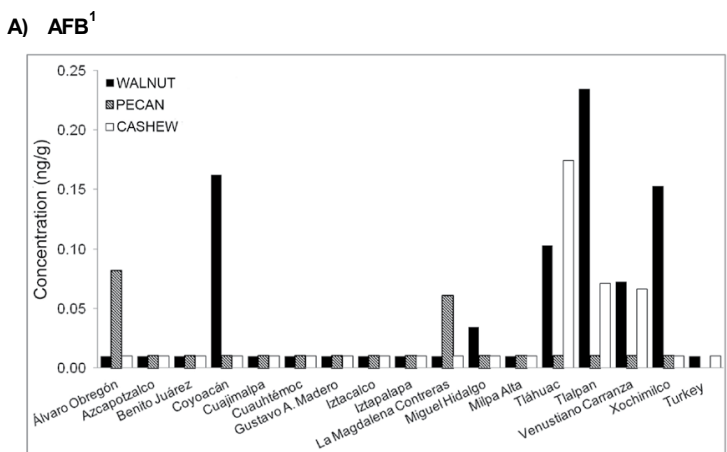

B)

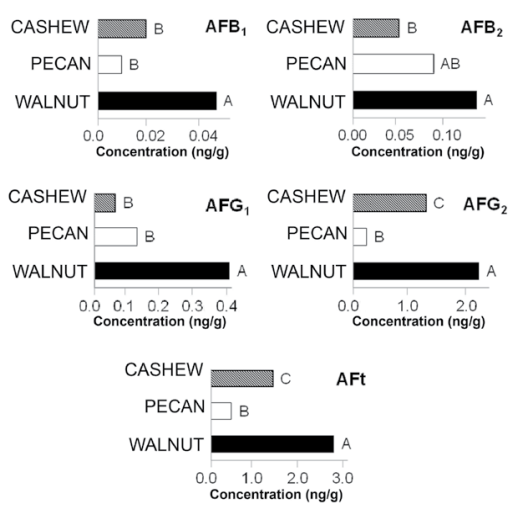

Figure 4. A) Average $\mathrm{AFB}_{1}(\mathrm{ng} / \mathrm{g})$ concentration ( $\left.\angle \mathrm{LOD}=0.01 \mathrm{ng} / \mathrm{g}\right)$ in Mexico City boroughs and Turkey for the three nuts. B) Average aflatoxin content in the studied nuts. Groups with different letters (A $B, C)$ have a significant difference $(p<0.05)$

lethal dose of $\mathrm{AFB}_{1} 0.36 \mathrm{mg} / \mathrm{kg}$ body weight is a special range of highly toxic poison (aflatoxin animal half of the lethal dose is found in the strongest carcinogens). Its carcinogenicity is 900 times more than dimethylnitrosamine induced liver cancer in the large capacity 75 times higher than the 3,4-benzopyrene, a large 4000-fold. It is mainly to induce liver cancer in animals, can also induce cancer, renal cancer, colorectal cancer and breast, ovary, small intestine and other sites of cancer.

The aflatoxicoses was characterized by high fever, high colored urine, vomiting, and edema of feet, jaundice, rapidly developing ascitis, portal hypertension and a high mortality rate. The disease was confirmed to the very poor, who were forced by economic circumstances to consume badly molded corn containing AF between $6.25-15.6 \mathrm{ppm}$, an average daily intake per person of 2-6 $\mathrm{mg}$ of aflatoxins [94].

In conclusion, the method was carefully validated, and no nut sample exceeded the limits established by Mexican legislation for AFt $(20 \mu \mathrm{g} / \mathrm{kg})$ in food for humans and $10 \mu \mathrm{g} / \mathrm{kg}$ AFt for the pecan. The walnut samples from the Tlalpan $(0.23 \mathrm{ng} / \mathrm{g})$ and Coyoacán $(0.16$ 
Citation: Citation: Adaya-González, J, Carvajal-Moreno, M, Rojo-Callejas, F and Ruiz-Velasco, S.(2015) Aflatoxins in Walnut (Juglans regia L.), Pecan (Carya illinoinensis (Wangenh.) K. Koch) and Cashew (Anacardium occidentale L.) Nuts of Mexico. Pharm Anal Acta 6: 338. doi:10.4172/2153-2435.1000338

Page 8 of 10

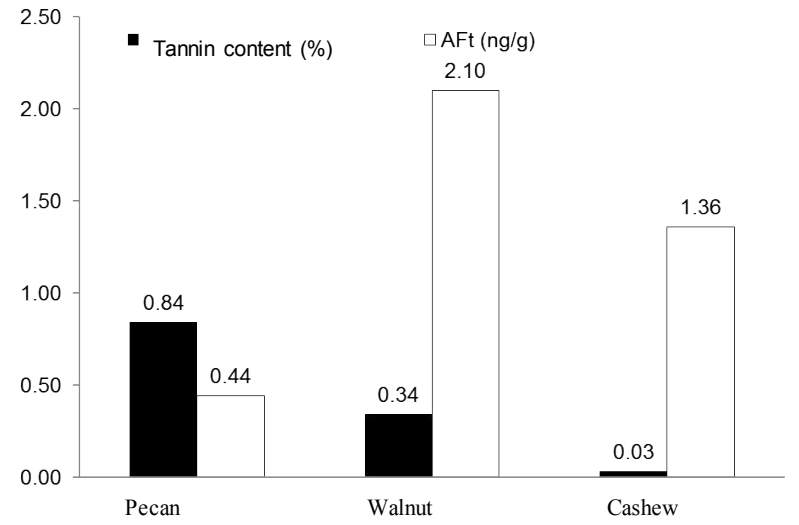

Figure 5. Correspondence between total aflatoxin (AFt) obtained and percentage of tannin content in the three nuts reported by Venkatachalan and Sathe (2006) [85].

$\mathrm{ng} / \mathrm{g}$ ) boroughs were the most contaminated by $\mathrm{AFB}_{1}$. The pecan and cashew were not significantly different based on sample origin for $\mathrm{AFB}_{1}$ content. There was no significant difference in AFt content with respect to sample origin.

The average contamination of the walnut for $\mathrm{AFB}_{1}(0.05 \mathrm{ng} / \mathrm{g})$ and AFt $(2.10 \mathrm{ng} / \mathrm{g})$ was significantly $(\mathrm{p}<0.05)$ higher than that for the cashew $\left(\mathrm{AFB}_{1}, 0.02 \mathrm{ng} / \mathrm{g}\right.$ and $\left.\mathrm{AFt}, 1.36 \mathrm{ng} / \mathrm{g}\right)$ and the pecan $\left(\mathrm{AFB}_{1}, 0.01\right.$ $\mathrm{ng} / \mathrm{g}$ and $\mathrm{AFt}, 0.44 \mathrm{ng} / \mathrm{g})$.

The yearly contribution of $\mathrm{AFB}_{1}(24 \mathrm{ng} / \mathrm{g})$ and AFt $(1300 \mathrm{ng} / \mathrm{g})$ from nuts to the diet of an inhabitant of Mexico City is under the tolerable limit.

\section{Acknowledgements}

The authors would like to thank the Instituto de Biologia, Universidad Nacional Autónoma de México for supporting this work. We would like to thank Joe Villavicencio, Jorge López, Alfredo Wong, Diana Martínez and Julio César Montero for computer assistance and design. Additionally, we would like to thank Georgina Ortega Leite and Gerardo Arévalo for library information.

\section{References}

1. FAO [Food and Agriculture Organization of the United Nations] (2012) FAOSTAT.

2. WPR [World Population Review] (2014). Accessed 9 sep 2014 Available on March 20th, 2014

3. COESPO, Consejo Estatal de Población (2012) Población total del Estado de México por Municipio. Secretaría General de Gobierno (Consulted 5 April, 2014).

4. INEGI [Instituto Nacional de Estadística y Geografía] (2010) Delimitación de las zonas Metropolitanas de México 2010.

5. Akande KE, Abubakar MM, Adegbola TA, Bongoro SE (2006). Nutritional and Health implications of mycotoxins in animal feeds: A review. Pak J Nutr 5: 398403.

6. Asao T, Büchi G, Abdel-Kader MM, Chang SB, Wick EL, et al. (1965) The Structures of Aflatoxins B and G. J Am Chem Soc 87: 882-886.

7. Carnaghan RBA, Hartley RD, O'Kelly J (1963) Toxicity and Fluorescence Properties of the aflatoxins. Nature 200: 1101.

8. Cheraghali AM, Yazdanpanah H, Doraki N, Abouhossain G, Hassibi M, et al (2007) Incidence of aflatoxins in Iran pistachio nuts. Food Chem Toxicol 45: 812-816.

9. Cabañes FJ, Abarca ML, Bragulat MR, Castella G (2007) Especies productoras de micotoxinas [Mycotoxin productive species]. In: J.M. Ramos ed. Micotoxinas en Alimentos. España: Ediciones Díaz de Santos, pp. 29-61.
10. Campbell BC, Molyneux RJ, Schatzki TF (2003) Current research on reducing pre-and post harvest aflatoxin contamination of US almond, pistachio, and walnut. J Toxicol Toxin Rev 22: 225-266.

11. Sanchis V, Marín S, Ramos AJ (2007) Factores determinantes en la producción de micotoxinas [Determinant factors in mycotoxin production]. In: Ramos JM ed. Micotoxinas en Alimentos. España: Ediciones Díaz de Santos, pp. 63-89. In Spanish.

12. SIAP [Servicio de Información Agroalimentaria y Pesquera] (2012) Producción annual.

13. Kendall CW, Josse AR, Esfahani A, Jenkins DJ (2010) Nuts, metabolic syndrome and diabetes. Br J Nutr 104: 465-473.

14. Fuller G, Spooncer WW, King AD, Schade J, Mackey B (1977) Survey of aflatoxins in California tree nuts. J Am Oil Chem Soc 54: A231-A234.

15. Feizy J, Beheshti HR, Fahim NK, Janati SS, Davari G (2010) Survey of aflatoxins in rice from Iran using immunoaffinity column clean-up and HPLC with fluorescence detection. Food Addit Contam Part B Surveill 3: 263-267.

16. Bayman P, Baker JL, Mahoney NE (2002) Aspergillus on tree nuts: incidence and associations. Mycopathologia 155: 161-169.

17. Decastelli L, Lai J, Gramaglia M, Monaco A, Nachtman C, et al. (2007) Aflatoxins occurrence in milk and feed in Northern Italy during 2004-2005. Food Control 18:1263-1266.

18. Wogan GN (1992) Aflatoxins as risk factors for hepatocellular carcinoma in humans. Cancer Res 52: 2114s-2118s.

19. Lindner E (1995) Toxicología de alimentos. 2a Ed. Acribia S.A. Zaragoza, Esp.

20. Olsen JH, Dragsted L, Autrup H (1988) Cancer risk and occupational exposure to aflatoxins in Denmark. Br J Cancer 58: 392-396.

21. IARC Working Group on the Evaluation of Carcinogenic Risks to Humans (2002) Some traditional herbal medicines, some mycotoxins, naphthalene and styrene. IARC Monogr Eval Carcinog Risks Hum 82: 1-556.

22. Park JW, Kim EK, Kim YB (2004) Estimation of the daily exposure of Koreans to aflatoxin B1 through food consumption. Food Addit Contam 21: 70-75.

23. Llewellyn GC, Stephenson GA, Hofman JW (1977) Aflatoxin B1 induced toxicity and teratogenicity in japanese Medaka eggs (Oryzias latipes). Toxicon 15: $582-587$

24. McLean M, Dutton MF (1995) Cellular interactions and metabolism of aflatoxin an update. Pharmacol Ther 65: 163-192.

25. Pier A, McLoughlin M (1985). Mycotoxin suppression of immunity. In Trichothecenes and other mycotoxins. Edit J. Lancey, John Wiley and Sons Ltd.

26. Eaton DL, Groopman JD (1994) The toxicology of aflatoxins. Human health, veterinary and agricultural significance. pp. 6-8 Academic press, San Diego, Ca.USA.

27. Bottalico A (1999). Mycotoxins in foods with possible human health implication Part 1-Aflatoxins. Igiene Moderna 111: 133-169.

28. Ross RK, Yuan JM, Yu MC, Wogan GN, Qian GS, et al. (1992) Urinary aflatoxin biomarkers and risk of hepatocellular carcinoma. Lancet 339: 943-946.

29. Williams JH, Phillips TD, Jolly PE, Stiles JK, Jolly CM, et al. (2004) Human aflatoxicosis in developing countries: a review of toxicology, exposure, potentia health consequences, and interventions. Am J Clin Nutr 80: 1106-1122.

30. Azziz-Baumgartner E, Lindblade K, Gieseker K, Rogers HS, Kieszak S, et al. (2005) Case-control study of an acute aflatoxicosis outbreak, Kenya, 2004 Environ Health Perspect 113: 1779-1783.

31. Groopman JD, Abbioni G (1991) Detection of aflatoxin and its metabolites in human biological fluids. Pennington Center Nutrition Series, 1: 18-31.

32. Kensler TW, Egner PA, Wang JB, Zhu YR, Zhang BC, et al. (2004) Chemoprevention of hepatocellular carcinoma in aflatoxin endemic areas. Gastroenterology 127: S310-318.

33. Wild CP, Hall AJ (2000) Primary prevention of hepatocellular carcinoma in developing countries. Mutat Res 462: 381-393.

34. (2002) OPS [Organización Panamericana de la Salud] La Salud de las Américas, pp: 449 
Citation: Citation: Adaya-González, J, Carvajal-Moreno, M, Rojo-Callejas, F and Ruiz-Velasco, S.(2015) Aflatoxins in Walnut (Juglans regia L.), Pecan (Carya illinoinensis (Wangenh.) K. Koch) and Cashew (Anacardium occidentale L.) Nuts of Mexico. Pharm Anal Acta 6: 338. doi:10.4172/2153-2435.1000338

35. (2005) OMS [Organización Mundial de la Salud] Cifras destacables: el impacto del cáncer.

36. Carvajal M, Berumen J, Guardado-Estrada M (2012) The presence of aflatoxin AFB1-FAPY adduct and human papilloma virus in cervical smears from cancer patients in Mexico. Food Addit Contam Part A Chem Anal Control Expo Risk Assess 29: 258-268.

37. Harrison JC, Carvajal M, Garner RC (1993) Does aflatoxin exposure in the United Kingdom constitute a cancer risk? Environ Health Perspect 99: 99-105.

38. Reye R, Morgan G, Baral J (1963) Encephalopathy and fatty degeneration of the viscera: A disease entity in childhood. Lancet 2: 749-752.

39. Groopman JD, Kensler TW (2005) Role of metabolism and viruses in aflatoxininduced liver cancer. Toxicol Appl Pharmacol 206: 131-137.

40. Apeagyei F, Lamplugh SM, Hendrickse RG, Affram K, Lucas S (1986) Aflatoxins in the livers of children with kwashiorkor in Ghana. Trop Geogr Med 38: $273-276$

41. Krishnamachari KA, Bhat RV, Nagarajan V, Tilak TB (1975) Hepatitis due to aflatoxicosis. An outbreak in Western India. Lancet 1: 1061-1063.

42. Gong Y, Hounsa A, Egal S, Turner PC, Sutcliffe AE, et al. (2004) Postweaning exposure to aflatoxin results in impaired child growth: a longitudinal study in Benin, West Africa. Environ Health Perspect 112: 1334-1338.

43. Lye MS, Ghazali AA, Mohan J, Alwin N, Nair RC (1995) An outbreak of acute hepatic encephalopathy due to severe aflatoxicosis in Malaysia. Am J Trop Med Hyg 53: 68-72.

44. Ngindu A, Johnson BK, Kenya PR, Ngira JA, Ocheng DM, et al. (1982) Outbreak of acute hepatitis caused by aflatoxin poisoning in Kenya. Lancet 1: 1346-1348.

45. Khoshpey B, Farhud D, Zaini F (2011) Aflatoxins in iran: nature, hazards and carcinogenicity. Iran J Public Health 40: 1-30.

46. Aksehirli M, Bozkurt M (1969) [Research from the standpoint of aflatoxin in filberts, pistacchios, shelled almonds, and walnuts in our country]. Turk Hij Tecr Biyol Derg 29: 103-112

47. Juan C, Zinedine A, Moltó JC, Idrissi L, Mañes J (2008) Aflatoxins levels in dried fruits and nuts from Rabat-Salé, Morocco. Food Control 19: 849-853.

48. Luttfullah G, Hussain A (2011) Studies on contamination level of aflatoxins in some dried fruits and nuts of Pakistan. Food Control 22: 426-429.

49. Koehler PE, Hanlin RT, Beraha L (1975) Production of aflatoxins B1 and G1 by Aspergillus flavus and Aspergillus parasiticus isolated from market pecans. Appl Microbiol 30: 581-583.

50. Leszczynska J, Kucharska U, Zegota $H$ (2000) Aflatoxins in nuts assayed by immunological methods. Eur Food Res Tech 210: 213-215.

51. McMeans JL (1983) Influence of yield on in vitro accumulation of aflatoxins in pecan (Carya illinoensis (Wang.) K. Koch) nutmeats. Appl Environ Microbio 45: $714-715$

52. Alwakee SS, Nasser LA (2011) Microbial contamination and mycotoxins from nuts in Riyadh, Saudi Arabia. Am J Food Technol 6: 613-630.

53. Herzallah S, Alshawabkeh K, Al Fataftah A (2008) Aflatoxin decontamination of artificially contaminated feeds by sunlight, É£-radiation, and microwave heating. J Appl Poultry Res 17: 515-521.

54. Midio AF, Campos RR, Sabino M (2001) Occurrence of aflatoxins B, B2, G1 and G2 in cooked food components of whole meals marketed in fast food outlets of the city of São Paulo, SP, Brazil. Food Addit Contam 18: 445-448.

55. Arrus K, Blank G, Abramson D, Clear R, Holley R (2005) Aflatoxin production by Aspergillus flavus in Brazil nuts. J Stored Prod Res 41: 513-527.

56. Trucksess, MW. 2007. "Natural toxins". In Official Methods of Analysis of AOAC International, 18th ed., Ed Horwitz, W and Latimer, GW Jr. 1-51. Gaithersburg (MD): AOAC International.

57. Akiyama H, Goda Y, Tanaka T, Toyoda M (2001) Determination of aflatoxins B B2, G1 and G2 in spices using a multifunctional column clean-up. J Chromatogr A 932: 153-157.

58. Kok WT (1994) Derivatization reactions for the determination of aflatoxins by liquid chromatography with fluorescence detection. J Chromatogr B Biomed Appl 659: 127-137.

59. Groopman JD, Donahue KF (1988) Aflatoxin, a human carcinogen determination in foods and biological samples by monoclonal antibody affinity chromatography. J Assoc Off Anal Chem 71: 861-867.
60. Garner RC, Whattam MM, Taylor PJL, Stow MW (1993) Analysis of United Kingdom purchased spices for aflatoxins using an immunoaffinity column clean-up procedure followed by high-performance liquid chroma. J Chromatogr A. $648: 485-490$

61. Jaimez J, Fente CA, Vazquez BI, Franco CM, Cepeda A, et al. (2000) Application of the assay of aflatoxins by liquid chromatography with fluorescence detection in food analysis. J Chromatogr A 882: 1-10.

62. IRAM 32 [Norma del Instituto Argentino de Normalización y Certificación] (1997) Quantifying uncertainty in analytical measurement. Metrología. Vocabulario VIM. Guide Eurachem- Citac Guide: 2000

63. El tawila M, Neamatallah A, Serdar S (2012) Incidence of aflatoxins in commercial nuts in the Holy city of Mekkah. Food Control 29: 121-124.

64. Leong YH, Ismail N, Latif AA, Ahmad R (2010) Aflatoxin occurrence in nuts and comercial nutty products in Malaysia. Food Control 21: 334-338.

65. Hesseltine CW, Shotwell OL, Smith M, Elis JJ, Vandergraft E, et al. (1970) Production of various aflatoxins by strains of Aspergillus flavus series. 202-210. In: Herzberg M. ed. Toxic Micro-organisms. UJNR and Dept. Interior, U.S. Gov. Printing Off., Washington, DC. pp. 490.

66. Davis ND, Urban L (1983) Some characteristics of toxigenic and nontoxigenic isolates of Aspergillus flavus and Aspergillus parasiticus. In: Diener UL, Asquith $\mathrm{RL}$, Dickens JW. eds. Aflatoxins and Aspergillus flavus in corn. Southern Cooperative Series Bulletin 279. Craftmaster Printers, Inc. Opelika, Alabama. pp 1-5.

67. Buchanan RL Jr, Ayres JC (1975) Effect of initial pH on aflatoxin production Appl Microbiol 30: 1050-1051.

68. Van Egmond HP, Visconti A, Boenke A, Speijers GJA (1995) Mycotoxins and Toxic Plant Components. New York: Wiley, pp. 204.

69. Baltaci C, llyasoğlu H, Yuksel F (2012) Single-Laboratory validation for the determination of Aflatoxin B, B2, G, and G2 in foods based on Immunoaffinity column and Liquid Chromatography with postcolumn derivatization and fluorescence detection. Food Anal Method 6: 36-44.

70. European Commission Rules (2010) Documento de orientacion para las autoridades competentes en materia de control del cumplimiento de la legislacion de la UE sobre aflatoxinas

71. Martínez ML, Labuckas DO, Lamarque AL, Maestri DM (2010) Walnut (Juglans regia L.): genetic resources, chemistry, by-products. J Sci Food Agric 90: 19591967.

72. Griel AE, Kris-Etherton PM (2006) Tree nuts and the lipid profile: a review of clinical studies. Br J Nutr 96 Suppl 2: S68-78.

73. Tocco G, Fais A, Meli G, Begala M, Podda G, et al. (2009) PEG-immobilization of cardol and soluble polymer-supported synthesis of some cardol-coumarin derivatives: Preliminary evaluation of their inhibitory activity on mushroom tyrosinase. Bioorg Med Chem Lett 19: 36-39.

74. Davis L, Stonehouse W, Loots du T, Mukuddem-Petersen J, van der Westhuizen $\mathrm{FH}$, et al. (2007) The effects of high walnut and cashew nut diets on the antioxidant status of subjects with metabolic syndrome. Eur J Nutr 46 155-164.

75. Gobierno de Chile, Ministerio de Agricultura [Chile Government, Ministry of Agriculture] (2004) El cultivo del pecano (Carya illinoinensis).

76. Sudzuki F (1996) Frutales subtropicales para Chile [Subtropical fruit trees for Chile]. Universitaria. Santiago, Chile. 218 p.

77. Fetuga B, Babatunde G, Oyenuga V (1974) Composition and nutritive value of cashew nut to the rat. J Agric Food Chem 22: 678-682.

78. FAO [Food and Agriculture Organization of the United Nations] (2006) Fichas tecnicas. Productos frescos y procesados. Maranon.

79. Mazzetto SE, Lomonaco D, Mele G (2009) Oleo da castanha de caju: oportunidades e desafios no contexto do desenvolvimento e sustentabilidade industrial. Quimica Nova 32: 732-741.

80. Agostini-Costa TS, Jales KA, Oliveira MEB, Garruti DS (2005) Determinaçao espectrofotometrica de acido anacardico em amendoas de castanhas de caju. Comunicado Tecnico 122, EMBRAPA, Brasilia, Maio.

81. Mahoney N, Molyneux RJ, McKenna J, Leslie CA, McGranahan G (2003) Resistance of 'Tulare' walnut (Juglans regia cv. Tulare) to aflatoxigenesis. J Food Sci 68: 619-622. 
Citation: Citation: Adaya-González, J, Carvajal-Moreno, M, Rojo-Callejas, F and Ruiz-Velasco, S.(2015) Aflatoxins in Walnut (Juglans regia L.), Pecan (Carya illinoinensis (Wangenh.) K. Koch) and Cashew (Anacardium occidentale L.) Nuts of Mexico. Pharm Anal Acta 6: 338. doi:10.4172/2153-2435.1000338

82. Mahoney N, Molyneux RJ, Kim JH, Campbell BC, Waiss AC, et al. (2010). Aflatoxigenesis induced in Aspergillus flavus by oxidative stress and reduction by phenolic antioxidants from tree nuts. World Mycot J 3: 49-57.

83. Mahoney N, Molyneux RJ (2004) Phytochemical inhibition of aflatoxigenicity in Aspergillus flavus by constituents of walnut (Juglans regia). J Agric Food Chem 52: 1882-1889.

84. Molyneux RJ, Mahoney N, Kim JH, Campbell BC (2007) Mycotoxins in edible tree nuts. Int J Food Microbiol 119: 72-78.

85. Venkatachalam M, Sathe SK (2006) Chemical composition of selected edible nut seeds. J Agric Food Chem 54: 4705-4714.

86. Abdulkadar AHW, Al-Ali A, Al-Jedah JH (2000) Aflatoxin contamination in edible nuts imported in Qatar. Food Control 11: 157-160.

87. Abdulkadar AH, Al-Ali A, Al-Jedah JH (2002) Occurrence of aflatoxin in commodities imported into Qatar, 1997-2000. Food Addit Contam 19: 666-670.

88. Creppy EE (2002) Update of survey, regulation and toxic effects of mycotoxins in Europe. Toxicol Lett 127: 19-28.
89. FAO, Food and Agriculture Organization of the United Nations (2004) Worldwide regulations for mycotoxins in food and feed in 2003. FAO Food and Nutrition Paper, No. 81. Rome: FAO.

90. Papp E, H-Otta K, Záray G, Mincsovic E (2002) Liquid chromatography determination of aflatoxins. Microchem J 73: 39-46.

91. Directive Commission (1998) 98/53/EC of 16 July 1998 laying down the sampling methods and the methods of analysis for the official control of the levels for certain contaminants in foodstuffs. CELEX-EUR Official Journal L 20 17 July 1998, pp. 93-101.

92. Norma Oficial Mexicana (2002) De productos y servicios. Control de aflatoxinas en cereales para consumo humano y animal. Especificaciones sanitarias. Diario Oficial de la Federación. Norma Oficial Mexicana, 15 de octubre NOM188-SSA1-2002. 22-30.

93. Lawley R (2013) Aflatoxins. Food Safety Watch.

94. Krishnamachari KA, Bhat RV, Nagarajan V, Tilak TB (1975). Investigations into outbreak of hepatitis in parts of Western India. Indian J Med Res 63:1036-1049.

95. Keeler RF, Tu AT (1983) Handbook of natural toxins . Vol. I. Plant and fungal toxin, New York, Marcel Dekker Inc. 